\title{
EFEKTIFITAS PENGGUNAAN MODEL PEMBELAJARAN FLIPPED CLASROOM TERHADAP KEMAMPUAN BERPIKIR KREATIF MATEMATIKA SISWA DI KELAS VIII SMP NEGERI 9 PADANGSIDIMPUAN
}

\author{
Oleh: \\ Rahel Situmeang, Muhammad Syahril Harahap, Rahmatika Elindra \\ Fakultas Matematika dan Ilmu Pengetahuan Alam \\ Institut Pendidikan Tapanuli Selatan
}

\begin{abstract}
The aim of this study is to describe the effectiveness of using flipped classroom learning model on students' creative thinking ability at the eighth grade students of SMP Negeri 9 Padangsidimpuan. This research was conducted by applying experimental (one group pre test post test design) with 27 students as the sample and they were taken by using cluster random sampling technique from 169 students. Observation and test were used in collecting the data. Based on descriptive analysis, it was found: (a) the average of using flipped classroom learning model was 3.66 (good category) and (b) the average of students' creative thinking ability before using flipped classroom learning model was 40.19 (fail category) and after using flipped classroom learning model was 79.93 (good category). Furthermore, by using pair sample $t_{\text {test }}$ and $N$-Gain, the result showed the significant value was less than $0.05(0.000<0.05)$ and $g=0.81$. It means using flipped classroom learning model had medium effective on students' creative thinking ability.
\end{abstract}

Keywords: flipped classroom learning model, students' creative thinking ability

\section{ABSTRAK}

Tujuan dari penelitian ini adalah untuk mendeskripsikan keefektifan penggunaan model pembelajaran flipped classroom pada kemampuan berpikir kreatif matematis siswa pada siswa kelas delapan SMP Negeri 9 Padangsidimpuan. Penelitian ini dilakukan dengan menerapkan eksperimen (satu kelompok pre test post test design) dengan 27 siswa sebagai sampel dan mereka diambil dengan menggunakan teknik cluster random sampling dari 169 siswa. Observasi dan tes digunakan dalam mengumpulkan data. Berdasarkan analisis deskriptif, ditemukan: (a) rata-rata menggunakan model pembelajaran flipped classroom adalah 3,66 (kategori sangat baik) dan (b) rata-rata kemampuan berpikir kreatif matematis siswa sebelum menggunakan model pembelajaran flipped classroom adalah 40.19 (kategori gagal) dan setelah menggunakan model pembelajaran flipped classroom adalah 75.93 (kategori baik). Selanjutnya, dengan menggunakan pair sample $t_{\text {test }}$ dan $\mathrm{N}$-Gain, hasilnya menunjukkan nilai signifikan kurang dari 0,05 (0,000 $<0,05)$ dan $g=0,68$. Ini berarti menggunakan model pembelajaran flipped classroom memiliki efektifitas yang sedang pada kemampuan berpikir kreatif matematis siswa.

Kata kunci: model pembelajaran flipped classroom, kemampuan berpikir kreatif matematis siswa

\section{PENDAHULUAN}

Pendidikan adalah upaya yang dapat mempercepat pengembangan potensi manusia untuk mampu mengemban tegas yang dibebankan kepadanya karena manusia yang dapat dididik dan mendidik. Pendidikan merupakan suatu usaha sadar yang dilakukan secara sistematis dalam mewujudkan suasana belajar-mengajar agar para peserta didik aktif dan dapat mengembangkan potensi dirinya untuk memiliki kekuatan spiritual keagamaan, pengembalian diri, kepribadian, kecerdasan, ahlak mulia, serta keterampilan yang bermanfaat bagi dirinya sendiri dan masyarakat.

Berdasarkan observasi awal yang dilakukan peneliti di SMP Negeri 9 Padangsidimpuan, yaitu dengan memberikan tes pada materi sistem persamaan linier dua variabel (SPLDV) sebanyak satu soal, terdapat bahwa kemampuan berpikir kreatif matematika siswa masih rendah dapat dilihat dari lembar jawaban siswa, yakni dari 27 siswa, yang dapat menjawab soal dengan benar hanya 5 siswa dan 22 siswa menjawab salah atau hanya $18 \%$ siswa yang dapat menjawab soal sesuai dengan indikator kemampuan berpikir kreatif matematika siswa. Adapun upaya yang dilakukan oleh guru dalam meningkatkan pemahaman siswa terhadap materi pokok sistem persamaan linier dua variabel, misalnya pemberian latihan, pemberian les tambahan, penyediaan buku-buku Matematika, dan penyedian sarana dan prasarana sebagai pendukung kegiatan 
pembelajaran, namun metode tersebut belum banyak membantu dalam meningkatkan kemampuan berpikir kreatif matematika siswa.

Model Pembelajaran yang penulis gunakan adalah model pembelajaran flipped classroom yang dapat meningkatkan dan mengembangkan kemampuan berpikir kreatif matematika siswa. Adapun alasan penulis memilih model pembelajaran flipped clasroom ialah di karenakan model ini mampu menciptakan aktifitas pembelajaran yang efektif kaitannya dengan waktu dan efisien kaitannya dengan biaya, khususnya pada kegiatan pembelajaran yang menggunakan media dan teknologi (Alfina et al., 2021; Harahap \& Nasution, 2019; Siregar et al., 2020). Berdasarkan permasalahan di atas,maka penulis terdorong melakukan penelitian yang bertujuan untuk meningkatkan kemampuan berpikir kreatif matematika siswa dengan mengangkat judul "Efektivitas Penggunaan Model Pembelajaran Flipped Classroom Terhadap Kemampuan Berpikir Kreatif Matematika Siswa Di SMP Negeri 9 Padangsidimpuan”.

\section{METODE PENELITIAN}

Metode penelitian merupakan cara ilmiah agar bisa memperoleh dan bisa mengumpulkan data-data dengan fungsi dan tujuan tertentu untuk mendapatkan jawaban yang tepat atas apa yang menjadi pertanyaan pada objek penelitian.Arti dari metode penelitian dalah upaya untuk mengetahui sesuatu dengan rangkaian sistematis. Metode penelitian merupakan cara yang digunakan untuk melakukan penelitian untuk mencapai suatu kebenaran.Metode penelitian adalah suatu cabang ilmu pengetahuan yang membicarakan/mempersoalkan mengenai cara-cara melaksanakan penelitian (yaitu meliputi kegiatan-kegiatan mencari, mencatat, merumuskan, menganalisis, sampai menyusun laporannya)berdasarkan fakta-fakta atau gejala-gejala ilmiah (Narbuko dan Achmidi 2013:2 ). Berdasarkan pendapat para ahli diatas maka peneliti menarik kesimpulan bahwa Metode penelitian merupakan seperangkat upaya dan cara sistematis yang diterapkan oleh peneliti dalam rangka memperoleh jawaban atas apa yang menjadi pertanyaan penelitiannya.Metode eksperimen merupakan sebagai metode penelitian yang digunakan untuk mencari pengaruh perlakuan tertentu terhadap yang lain dalam kondisi yang dikendalikan. Menurut Sugiyono (2014:334) "Metode penelitian eksperimen adalah metode penelitian yang digunakan untuk mencari pengaruh perlakuan tertentu terhadap yang lain dalam kondisi yang terkendalikan”. Berdasarkan uraian diatas, maka metode penelitian yang penulis gunakan ialah metode Eksperimen, dengan desain penelitian one-group pretest-posttest design

Populasi adalah jumlah keseluruhan dari satuan-satuan atau individu-individu yang karakteristiknya hendak diteliti. Menurut Rangkuti (2014:51) "populasi adalah serumpunan atau sekelompok objek yang menjadi sasaran penelitian".Dari pendapat para ahli diatas dapat disimpulkan bahwa populasi adalah sejumlah subjek yang dijadikan objek penelitian yang di tetapkan oleh peneliti untuk diketahui dan kemudian ditarik kesimpulannya.Berdasarkan pengertian populasi penelitian adalah keseluruhan siswa kelas VIII SMP Negeri 9Padangsidimpuan T.A 2019/2020 yang terdiri dari 7 kelas yang berjumlah 169 orang. Sampel adalah sebagian dari subjek dalam populasi yang di teliti, yang sudah tentu mampu dan dapat mewakili populasinya. Menurut Rangkuti (2014:51) "Sampel adalah sebagian objek yang mewakili populasi yang dipilih dengan cara tertentu"Dari pendapat para ahli diatas penulis menarik kesimpulan bahwa sampel itu merupakan dari bagian dari objek yang akan diteliti yang dilih sedemikian rupa hingga mewakili keseluruhan objek (populasi) yang ingin diteliti. Mengingat jumlah populasi yang sangat banyak dan keterbatasan waktu, maka pengambilan sampel menggunakan teknik. Adapun teknik pengambilan sampel yang digunakan oleh peneliti ialah cluster random sampling.

Data adalah merupakan faktor yang sangat penting, karena data merupakan keteranganketerangan yang diperlukan untuk memberikan kebenaran hipotesis. Untuk memperoleh data yang benar-benar obyektif dan lengkap, maka harus dibutuhkan suatu teknik pengumpulan data yang tepat. Jika terjadi kekeliruan didalam memilih metode pengumpulan data maka akan menyebabkan hasil penelitian tepat. Adapun macam teknik pengumpulan data yang dapat dugunakan dalam suatu penelitian, wawancara, observasi, quissioner, tes. Dari jenis teknik pengumpulan data diatas maka peneliti menggunakan tiga teknik, diantaranya:1) obsevasi dan 2) tes. Observasi digunakan untuk memperoleh data dari variabel penggunaan model pembelajaran Flepped Clasroom sedangkan tes digunakan untuk memperoleh Kemampuan berpikir kreatif matematika siswa. Setelah data diperoleh lalu dianalisis dengan statistik deskriptif dan statistik inferensial uji-t. 


\section{HASIL DAN PEMBAHASAN}

Deskripsi Penggunaan Model Pembelajaran Flipped Clasroom di Kelas VIII SMP Negeri 9 Padangsidimpuan

Berdasarkan kegiatan guru dalam proses pembelajaran dengan menerapkan model pembelajaran Flipped Clasroom, maka hasil analisis data skor yang diperoleh dari kedua observer menggunakan lembar observasi tentang model pembelajaran Flipped Clasroom di kelas VIII-3 SMP Negeri 9 Padangsidimpuan, diperoleh nilai terendah yaitu 0 dan nilai tertinggi adalah 1 dan nilai maksimum yang mungkin dicapai 4,00 dimana nilai tengah teoritisnya 2,00. Berdasarkan perhitungan yang telah peneliti lakukan, maka diperoleh nilai rata-rata (mean) senilai 3,66. Agar lebih mudah memahaminya dapat dilihat pada tabel berikut:

Tabel 1

Deskripsi Data Penggunaan Model Pembelajaran Flipped Clasroom di SMP Negeri 9 Padangsidimpuan

\begin{tabular}{llc} 
No & Observer & Nilai \\
\hline 1 & Yusra Erliana Harahap,S.Pd & 3,66 \\
\hline 2 & Srirejeki Sihotang & 3,66 \\
\hline Jumlah & 7,32 \\
\hline Rata-rata & 3,66
\end{tabular}

Deskripsi Data Kemampuan Berpikir Kreatif Matematika Siswa di Kelas VIII SMP Negeri 9 Padangsidimpuan sebelum Menerapkan Model Pembelajaran Flipped Clasroom

1. Kemampuan berpikir kreatif matematika siswa menggunakan model pembelajaran Flipped Clasroom di kelas VIII-3 SMP Negeri 9 Padangsidimpuan pada indikator berpikir lancar (Fluency) diperoleh skor rata-rata 52,03 Nilai tersebut apabila dikonsultasikan pada tabel 21 berada pada kategori "Kurang". Yang artinya siswa belum mampu dalam memecahkan suatu permasalahan dan menghasilkan ide yang baru secara lancar dan hal tersebut perlu untuk ditingkatkan.

2. Kemampuan berpikir kreatif matematika siswa menggunakan model pembelajaran flipped clasroom di kelas VIII-3 SMP Negeri 9 Padangsidimpuan pada indikator berpikir fleksibel (Flexibility) diperoleh skor rata-rata 38,14 Nilai tersebut jika dikonsultasikan pada tabel 21 berada pada kategori "Gagal". Artinya siswa belum mampu memecahkan suatu permasalahan dan menghasilkan ide yang baru dan bervariasi dalam melaksanakan suatu kegiatan dan hal tersebut sangat perlu untuk ditingkatkan.

3. Kemampuan berpikir kreatif matematika siswa menggunakan model pembelajaran flipped clasroom di kelas VIII-3 SMP Negeri 9 Padangsidimpuan pada indikator berpikir merinci (Eleboration) diperoleh skor rata-rata 29,81 Nilai tersebut, apabila dikonsultasikan pada tabel 21 berada pada kategori "Gagal". Artinya siswa belum mampu memecahkan suatu permasalahan dan menghasilkan ide yang baru untuk dikembangkan dan dirincikan secara detail dalam melaksanakan suatu kegiatan, dan hal tersebut sangat perlu untuk ditingkatkan di SMP Negeri 9 Padangsidimpuan demi tercapainya kualitas pendidikan yang bermutu.

Deskripsi Data Kemampuan Berpikir Kreatif Matematika Siswa di Kelas VIII SMP Negeri 9 Padangsidimpuan sesudah Menerapkan Model Pembelajaran Flipped Clasroom

1. Kemampuan berpikir kreatif matematika siswa menggunakan model pembelajaran Flipped Clasroom di kelas VIII-3 SMP Negeri 9 Padangsidimpuan pada indikator berpikir lancar (Fluency) diperoleh skor rata-rata 77,4 Nilai tersebut apabila dikonsultasikan pada tabel 21 berada pada kategori "Baik". Yang artinya siswa sudah mampu untuk mengikuti indikator didalam memecahkan suatu permasalahan dan menghasilkan ide-ide yang baru secara lancar didalam melaksanakan suatu kegiatan.

2. Kemampuan berpikir kreatif matematika siswa menggunakan model pembelajaran flipped clasroom di kelas VIII-3 SMP Negeri 9 Padangsidimpuan pada indikator berpikir fleksibel (Flexibility) diperoleh skor rata-rata 78,8 Nilai tersebut jika dikonsultasikan pada tabel 21 berada 
pada kategori "baik". Artinya siswa sudah mampu memecahkan suatu permasalahan dan menghasilkan ide yang baru dan bervariasi dalam melaksanakan suatu kegiatan

3. Kemampuan berpikir kreatif matematika siswa menggunakan model pembelajaran flipped clasroom di kelas VIII-3 SMP Negeri 9 Padangsidimpuan pada indikator berpikir merinci (Eleboration) diperoleh skor rata-rata 65,18 Nilai tersebut, apabila dikonsultasikan pada tabel 21 berada pada kategori "Cukup". Artinya siswa masih kurang mampu memecahkan suatu permasalahan dan menghasilkan ide yang baru untuk dikembangkan dan dirincikan secara detail dalam melaksanakan suatu kegiatan, dan hal tersebut sangat perlu untuk ditingkatkan di SMP Negeri 9 Padangsidimpuan demi tercapainya kualitas pendidikan yang bermutu.

\section{Pengujian Hipotesis}

\section{Uji Normalitas}

Uji normalitas dilakukan dengan tujuan untuk mengetahui apakah sebaran data yang diperoleh berdistribusi normal atau tidak. Dengan ketentuan bahwa data berasal dari populasi normal jika memenuhi taraf signifikan $>0,05$. Hipotesis yang akan diajukan akan diuji dalam uji normalitas sebagai berikut:

Tabel 3

Data Kemampuan Berpikir Kreatif Matematika Siswa Menggunakan Mode Pembelajaran Flipped Clasroom di Kelas VIII-3 SMP Negeri 9 Padangsidimpuan

One-Sample Kolmogorov-Smirnov Test

\begin{tabular}{|cc|c|c|}
\hline & & prites & postes \\
\hline $\mathrm{N}$ & & 27 & 27 \\
Normal Parameters ${ }^{\mathrm{a}, \mathrm{b}}$ & Mean & 40,19 & 75,93 \\
& Std. Deviation & 9,015 & 11,715 \\
Most Extreme Differences & Absolute &, 162 &, 144 \\
& Positive &, 162 &, 108 \\
& Negative &,- 129 &,- 144 \\
& &, 162 &, 144 \\
Test Statistic &, $067^{\mathrm{c}}$ &, $160^{\mathrm{c}}$ \\
\hline
\end{tabular}

a. Test distribution is Normal

b. Calculated from data.

c. Lilliefors Significance Correction.

Jika signifikan lebih besar dari 0,05 maka dikatakan normal den sebaliknya, apa bila lebih kecil dari 0,05 maka dikatakan tidak normal. Berdasarkan tabel diatas hasil uji normalitas tentang kemampuan berpikir kreatif matematika siswa sebelum menggunakan model flipped clasroom diperoleh rata-rata 40,19 dengan sig >0,05, yaitu 0,068>0,05 maka dapat disimpulkan bahwa data berdistribusi normal. Kemudian kemampuan berpikir kreatif matematika siswa menggunakan model pembelajaran flipped clasroom diperoleh rata-rata 75,93 dengan sig $>0,05$, yaitu o,16>0,05 maka data yang diperoleh berdistribusi normal. Sehingga dapat disimpulkan bahwa data tentang kemampuan berpikir kreatif matematika siswa materi pokok lingkaran pada tes awal (pritest) dan tes akhir (posttes) di kelas VIII-3 SMP Negeri 9 Padangsidimpuan berada dalam sebaran normal.

\section{Uji Homogenitas}

Uji homogenitas ini digunakan untuk mengetahui apakah sampel yang diambil mempunyai varian yang sama atau tidak. Jika kedua kelompok mempunyai varian yang sama maka kelompok tersebut homogen. Untuk menguji homogenitas varian dari kedua sampel, maka digunakan uni homogenitas menggunakan one way anova. Uji homogenitas nilai prites dan posttest kemampuan berpikir kreatif matematika siswa dilakukan melalui perhitungan SPSS 22 dengan kriteria sebagai berikut:

a. Nilai signifikan $<0,05$ maka data mempunya varians tidak sama/tidak homogen

b. Nilai signifikan $\geq 0,05$ maka data mempunyai varians sama/ homogen

\section{Tabel 4}

Uji Homogenitas Kemampuan Berpikir Kreatif Matematika Siswa Test of Homogeneity of Variances prites 


\begin{tabular}{|l|l|l|l|}
\hline Levene Statistic & df1 & df2 & Sig. \\
\hline 1,793 & 6 & 13 &, 178 \\
\hline
\end{tabular}

Uji homogenitas menunjukkan bahwa nilai kemampuan berpikir kreatif matematika siswa pritest dan postest pada penelitian ini adalah homogen. Dimana nilai signifikan $>0,05$ yaitu $0,178>0,05$.

\section{Uji Hipotesis}

Untuk mengetahui koefisien korelasi antara kedua variabel, penulis menggunakan uji-t. Dalam hal ini, penulis akan menganalisis uji hipotesis menggunakan sofware SPSS 22 dengan taraf signifikan $\mathrm{a}=0,05$ dengan kriteria uji-t sebagai berikut:

a. Ha diterima apabila nilai signifikan $<0,05$.

b. Ha ditolak apabila signifikan $>0,05$

Tabel 5

Hasil Uji "T" Kemampuan Berpikir Kreatif Matematika Siswa data Pritest dan Posttest di Kelas VIII-3 SMP Negeri 9 Padangsidimpuan

Paired Samples Test

\begin{tabular}{|c|c|c|c|c|c|c|c|c|}
\hline & \multicolumn{5}{|c|}{ Paired Differences } & \multirow[b]{3}{*}{$\mathrm{t}$} & \multirow{3}{*}{$\begin{array}{l}d \\
f\end{array}$} & \multirow{3}{*}{$\begin{array}{l}\text { Sig. }(2- \\
\text { tailed })\end{array}$} \\
\hline & \multirow{2}{*}{$\begin{array}{l}\text { Mea } \\
n\end{array}$} & \multirow{2}{*}{$\begin{array}{l}\text { Std. } \\
\text { Deviatio } \\
\mathrm{n}\end{array}$} & \multirow{2}{*}{$\begin{array}{l}\text { Std. Error } \\
\text { Mean }\end{array}$} & \multicolumn{2}{|c|}{$\begin{array}{l}95 \% \text { Confidence Interval of } \\
\text { the Difference }\end{array}$} & & & \\
\hline & & & & Lower & Upper & & & \\
\hline $\begin{array}{ll}\text { Pai } & \text { pritest } \\
\text { r } 1 & \text { postest }\end{array}$ & $\begin{array}{l}- \\
35,7 \\
41\end{array}$ & 14,910 & 2,869 & $-41,639$ & $-29,843$ & $\begin{array}{l}- \\
12,4 \\
56\end{array}$ & $\begin{array}{l}2 \\
6\end{array}$ & ,000 \\
\hline
\end{tabular}

Berdasarkan tabel diatas diperoleh nilai signifikan sebesar 0,0000. Dengan demikian berarti nilai sig <0,05 maka hipotesis alternatif $\mathrm{Ha}$ yang ditegakkan dalam penelitian ini diterima atau disetujui kebenarannya, artinya "Model Pembelajaran Flipped Clasroom efektif terhadap kemampuan berpikir kreati matematika siswa di SMP Negeri 9 Padangsidimpuan".

\section{Pembahasan}

Hasil analisis data yang diperoleh yaitu pada tes awal (pritest) di kelas VIII-3 SMP Negeri 9 Padangsidimpuan diperoleh nilai rata-rata indikator pertama yaitu berpikir lancar (fluency) sebesar 52,03 berada pada kategori "Kurang". Kemudian nilai rata-rata indikator kedua yaitu berpikir fleksibel(Flexibility) sebesar 38,14 berada pada kategori "Gagal". dan nilai rata yang diperoleh dari indikator terahir yaitu berpikir merinci (elaboration) sebesar 29,81 dan nilai tersebut berada pada kategori "Gagal”. Dari nilai rata-rata ketiga indikator pada tes awal (pritest) dapat diketahui bahwa siswa masih sangat kurang didalam memecahkan suatu permasalahan dan menghasilkan ide-ide yang baru secara lancar, dan siswa juga tidak mampu dalam memecahkan masalah dan memperoleh ide yang baru serta siswa tidak mampu memperinci suatu permasalahan matematika. Selanjut nya hasil tes ahir (posttest) sesudah menggunakan model pembelajaran flipped clasroom diperoleh nilai rata-rata kemampuan berpikir kreatif matematika siswa dikelas VIII-3 SMP Negeri 9 Padangsidimpuan sebesar 77,4 pada indikator pertama yaitu berpikir lancar (elaboration) berada pada kategori "Baik". Nilai rata-rata pada indikator kedua yaitu berpikir fleksibel (flexibility) ialah sebesar 77,88, berada pada kategori "Baik". Dan terakhir nilai rata-rata pada indikator ketiga yaitu berpikir merinci (Elaboration) sebesar 65,18, nilai rata-rata tersebut berada pada kategori "Cukup". Hal tersebut menunjukkan bahwa terdapat peningkatan yang signifikan kemampuan berpikir kreatif matematika siswa sebelum dan sesudan menerapkan model pembelajaran flipped clasroom. Disamping itu juga penelitian yang dilakukan oleh penulis dikuatkan oleh penelitian Apriyanah (2018) dengan judul "Efektifitas Penggunaan Model Pembelajaran Flipped Clasroom Pada Pembelajaran Fisika Ditinjau dari Self Eficacy dan Penguasaan Konsep Siswa". Hasil penelitian yang diperoleh oleh Pipit Apriyanah menunjukkan bahwa terdapat perbedaan rata-rata self efficacy dan penguasaan konsep siswa pada kelas eksperimen dan kelas kontrol yang artinya penerapan model pembelajaran flipped clasroom pada proses pembelajaran memberikan pengaruh yang signifikan terhadap self efficacy dan penguasaan konsep siswa dibandingkan dengan pembelajaran yang menggunakan model konvensional. 
ISSN. 2621-9832

JURNAL MathEdu (Mathematic Education Journal) http://journal.ipts.ac.id/index.php/MathEdu

Vol. 4 No. 2 Juli 2021

\section{KESIMPULAN DAN SARAN \\ Kesimpulan}

Berdasarkan hasil penelitian yang dilakukan, penulis menarik beberapa kesimpulan yang didasarkan pada hasil pengumpulan data. Adapun kesimpulan tersebut adalah sebagai berikut: 1. Gambaran penerapan model pembelajaran flipped clasroom di SMP Negeri 9 Padangsidimpuan diperoleh nilai rata-rata 3,66 termasuk padakategori "Baik". Arinya proses pembelajaran sudah terlaksana sesuai dengan kaidah ataupun aturan-aturan model pembelajaran flipped clasroom.

2. Gambaran kemampuan berpikir kreatif matematika siswa di SMP Negeri 9 Padangsidimpuan sebelum menerapkan model Pembelajaran flipped clasroom diperoleh nilai rata-rata sebesar 40,19 beradapada kategori "Gagal". Dan sesudah penerapan model pembelajaran flipped clasroom diperoleh nilai rata-rta sebesar 75,93 berada pada kategori "Baik"

3. Penerapan model pembelajaran flipped clasroom efektif terhadap kemampuan berpikir kreatif matematika siswa di SMP Negeri 9 Padangsidimpuan dapat dilihat dari lembar observasi sebesar 3,66 beradapada kategori "Sangat Baik", artinya langkah-langkah model pembelajaran flipped clasroom sudah diterapkan sesuai kaidah ataupun aturan-aturan model pembelajaran flipped clasroom. Hasil penelitian pada pengujian hipotesis dari tabel pared simple T test dapat dilihat hipotesis alternatif $\left(\mathrm{H}_{\mathrm{a}}\right)$ yang ditegakkan diterima dan diperoleh nilai signifikan sebesar 0,000 dimana $0,000<0,05$. Serta besarnya efektifitas model pembelajaran flipped clasroom terhadap kemampuan berpikir kreatif matematika siswa jika dihitung menggunakan efect size adalah 0,68 berada pada kategori "Sedang".

\section{Saran}

Berdasarkan kesimpulan dan implikasi hasil penelitian diatas, adapun yang menjadi saran penulis adalah sebagai berikut:

1. Kepada siswa, diharapkan lebih giat lagi dan memperbaiki cara belajarnya dalam menerima pelajaran disekolah. Siswa harus lebih konsentrasi lagi dan juga harus lebih aktif dalam proses pembelajaran seperti aktif menemukan hal yang baru, menemukan pengetahuan baru, aktif bertanya dan berdiskusi salah satunya untuk meningkatkan kemampuan berpikir kreatif.

2. Kepada guru yang mengajar bidang studi matematika, diharapkan mampu untuk memilih dan menyesuaikan model pembelajaran dengan suasana belajar agar siswa lebih aktif dan mudah memahami materi yang diajarkan.

3. Kepada kepala sekolah, diharapkan dapat meningkatkan dan memberikan masukan kepada guru kelas agar lebih meningkatkan kemampuan mengajar dan memberikan penataran-penataran khususnya pada pelajaran matematika.

4. Kepada orang tua, diharapkan agar lebih memantau anaknya lebih baik lagi, terutama terhadap pendidikan anak, memfasilitasi dengan buku-buku pelajaran, sehingga mampu untuk meningkatkan kemampuan berpikir kreatif matematika .

5. Kepada peneliti lainnya, diharapkan dapat melanjutkan penelitian ini dengan melihat sisi lain dari masalah yang ada, agarpembelajaran matematika semakin berkualitas.

\section{DAFTAR PUSTAKA}

Alfina, N. S., Harahap, M. S., \& Elidra, R. (2021). EFEKTIVITAS PENGGUNAAN MODEL PEMBELAJARAN FLIPPED CLASSROOM TERHADAP KEMAMPUAN BERPIKIR KRITIS MATEMATIS SISWA DI SMA NEGERI 1 ANGKOLA BARAT. Jurnal MathEdu, 4(1), 97-106.

Elindra. Rahmatika - Eksakta 2017.Pengaruh Penggunaan Model Pembelajaran Creative Problem Solving (CPS) Terhadap Kemampuan Berfikir Kreatif Matematika Mahasiswa STKIP Tapanuli Selatan. Jurnal Penelitian dan Pembelajaran MIPA, 2017

Harahap,Rizki Alamsyah, Holila,Anni,Ahmad, Marzuki 2019.efektivitas pendekatan pendidikan matematika realistik terhadap kemampuan berpikir kreatif matematis siswa di sma negeri 1 portibi.JURNAL MathEdu (Mathematic Education Journal). Volume 2 Tahun 2019;64-74

Harahap. Muhammad, Syahril, Nasution. Sartika Rati Asmara (2019) EFEKTIVITAS PEMBELAJARAN FLIPPED CLASSROOM DILIHAT DARI KEMAMPUAN PEMECAHAN MASALAH MAHASISWA. Seminar Nasional Multi Disiplin Ilmu Universitas, 2019 
Harahap, M. S., \& Nasution, S. R. A. (2019). Efektivitas Pembelajaran Flipped Classroom dilihat dari Kemampuan Pemecahan Masalah Mahasiswa. Prosiding Seminar Nasional Multidisplin, 115-121.

Narbuko,Achmidi 2013. Metodologi Penelitian.jakarta.Penerbit Bumi Aksara.

Siregar, H. L., Harahap, M. S., \& Hakim, L. (2020). Efektivitas Penggunaan Model Pembelajaran Auditory, Intellectually, Repetition ( Air ) Terhadap Kemampuan Pemahaman. Efektivitas Penggunaan Model Pembelajaran Auditory, Intellectually, Repetition ( Air ) Terhadap Kemampuan Pemahaman, 3(3), 42-49.

Silaban, Transusi., Ahmad, Marzuki., \&Lubis,Roslian 2019. Efektifitas Model Pembelajaran Berbasis Masalah (PBS) Terhadap Kemampuan Berpikir Kreatif Matematika Siswa di SMP Negeri 1 Pinangsori.JURNAL MathEdu (Mathematic Education Journal). Volume 2 Tahun 2019;103-108

Rangkuti, Ahmad,Nijar 2014.Metode Penelitian Pendidikan.Bandung.Penerbit Cita pustaka Media Tahun 2018;91-99

Tampubolon, Cisilia 2018. Efektifitas Penggunaan Model Pembelajaran Triffinger Terhadap Kemampuan Berpikir Kreatif Siswa di Kelas X SMA Negeri 2 Siabu.JURNAL MathEdu (Mathematic Education Journal) :Volume 1

Yanti,Risma 2019.Efektifitas Penggunaan Model Pembelajaran Mea Terhadap Kemampuan Berpikir Kreatif Matematis Siswa Through Macro Media Flash Di Kelas XI SMA Negeri 1 Angkola Selatan.JURNAL MathEdu (MathematicEducationJournal)Volume 1 tahun 2019;42-50 